\title{
EXPERIMENTAL OBSERVATIONS ON PROPRANOLOL IN ANAESTHESIA *
}

\author{
Gerald B. H. Lewis, M.B., B.S., D.A. (R.C.P. \& S.) †
}

THE USE of solutions containing epinephrine by surgeons for the purpose of achieving local vasoconstriction during anaesthesia is an everyday occurrence, although it is well known that the danger of provoking ventricular arrhythmias is increased in the presence of certain anaestl stic agents. Recommendations concerning maximum dosage and rate of epineplirine injections have not led to the prevention of all such arrhythmias. ${ }^{1}$ The prophylactic administration of Propranolol (Inderal ${ }^{\oplus}$ ) has been shown to raise the threshold of the appearance of these arrhythmias. ${ }^{2,3}$ The entire subject of beta-adrenergic blockade and anaesthesia has been reviewed in this journal by Warner. ${ }^{4}$

It has been suggested that when arrhythmias occur, the best course is to discontinue the administration of the sensitizing anaesthetic agent and to ventilate the lungs with oxygen, advising the surgeon to await the rapid metabolism of the epinephrine in the hope that the arrhythmias will revert spontaneously. Obviously further epinephrine infiltration is contraindicated under these circumstances.

\section{Study I}

As propranolol has been used successfully in the treatment of a variety of arrhythmias, it was decided to test its efficacy against epinephrine-induced ventricular arrhythmias in the presence of various anaesthetic agents. Ventricular arrhythmias were produced by the intravenous injection of dilute epinephrine solutions. The efficacy of moderate doses of intravenous propranolol was compared to the effect of an equal volume of normal saline and to expectant nonintervention of any kind.

\section{Method}

Four mongrel dogs weighing between 35 and 45 pounds were used in the experiment. The Latin square full randomization method was applied, with each animal being anaesthetized at intervals of ten days with diethyl ether, azeotrope halothane/ether, halothane, or methoxyflurane, all in nitrous oxide 75 per cent, oxygen 25 per cent. Diethyl ether and the azeotrope were administered by a no. 8 Heidbrink ether vaporizer in amounts resulting in light anaesthesia, as judged by clinical criteria. Halothane was vaporized by means of a Fluotec vaporizer set at 0.5 per cent, and methoxyflurane by a Pentec vaporizer set at 0.25 per cent.

The animals were not premedicated. Anaesthesia was induced with intravenous

'Presented as part of the Residents' Programme at the Annual Meeting of the Canadian Anaesthetists' Society, Toronto, June 16-19, 1969.

†From the Department of Anaesthesia, University of Saskatchewan and University Hospital, Saskatoon, Saskatchewan. 
thiopental ( 2.5 per cent) $10 \mathrm{mg} / \mathrm{lb}$ body weight, followed by orotracheal intubation with a $9.0 \mathrm{~mm}$ cuffed tube. Maintenance was with a circle absorber system connected to a Bird Mark Iv respirator. Following induction of anaesthesia, an artery and a vein were cannulated to permit continuous monitoring of intra-arterial blood pressure and the intravenous injection of drugs. Blood pressure and electrocardiogram were monitored and recorded on a Grass polygraph. Baseline arterial blood gases were determined at that time and, if required, ventilation was adjusted to bring blood gas values within normal range.

The initial injection consisted of epinephrine $1: 10,000,0.125 \mathrm{ml}(12.5 \mu \mathrm{g})$ in normal saline which was administered slowly intravenously. If ventricular arrhythmias were not provoked, the dosage was doubled every two minutes until the desired result was obtained. This timing was adopted because it had been determined previously that blood pressure and pulse rate tended to return to baseline within two minutes of the intravenous injection of epinephrine.

The first ventricular arrhythmia so obtained was left untreated and the time to spontaneous reversion to sinus rhythm was noted. When this had occurred and the sinus rhythm had been re-established for a period of two minutes and if blood pressure and pulse rate had returned to former levels, an identical dose of epinephrine was injected to produce another episode of ventricular arrhythmia. On this occasion $1 \mathrm{ml}$ of normal saline was flushed into the circulation immediately upon the appearance of the arrhythmia. Again the time taken for reversion to sinus rhythm was noted. Two minutes after that had occurred the identical arrhythmiaprovoking dose of epinephrine was given once again. The resulting arrhythmia was now treated with propranolol $0.5 \mathrm{mg}$ in $1 \mathrm{ml}$, injected at the same rate as the preceding normal saline. Again the time to reversion to sinus rhythm was noted. This dose of propranolol used was equal, on a weight basis, to that recommended for the treatment of arrhythmias in man.

\section{Results}

The volume of epinephrine 1:10,000 required to induce ventricular arrhythmias with the various agents is tabulated in Figure 1. It will be seen that the amount required to produce these arrhythmias was generally much greater under diethyl ether anaesthesia than under the other anaesthetics, but showed considerable variation; halothane anaesthesia on the other hand required a consistently low dosage, with azeotrope halothane/ether and methoxyflurane in an intermediate position. There is evidence also that some animals are more susceptible to epinephrine than others.

In pilot experiments with twelve other dogs, sudden death occurred at times after as little as $0.125 \mathrm{ml}$ of epinephrine in 1:10,000 under halothane anaesthesia, but the danger of inducing sudden ventricular fibrillation was present even with diethyl ether. No animal under methoxyflurane anaesthesia succumbed, but this may be fortuitous. When death did occur under any anaesthetic, it always happened immediately after injection of the epinephrine and was never preceded by any prolonged period of ventricular arrhythmia. 


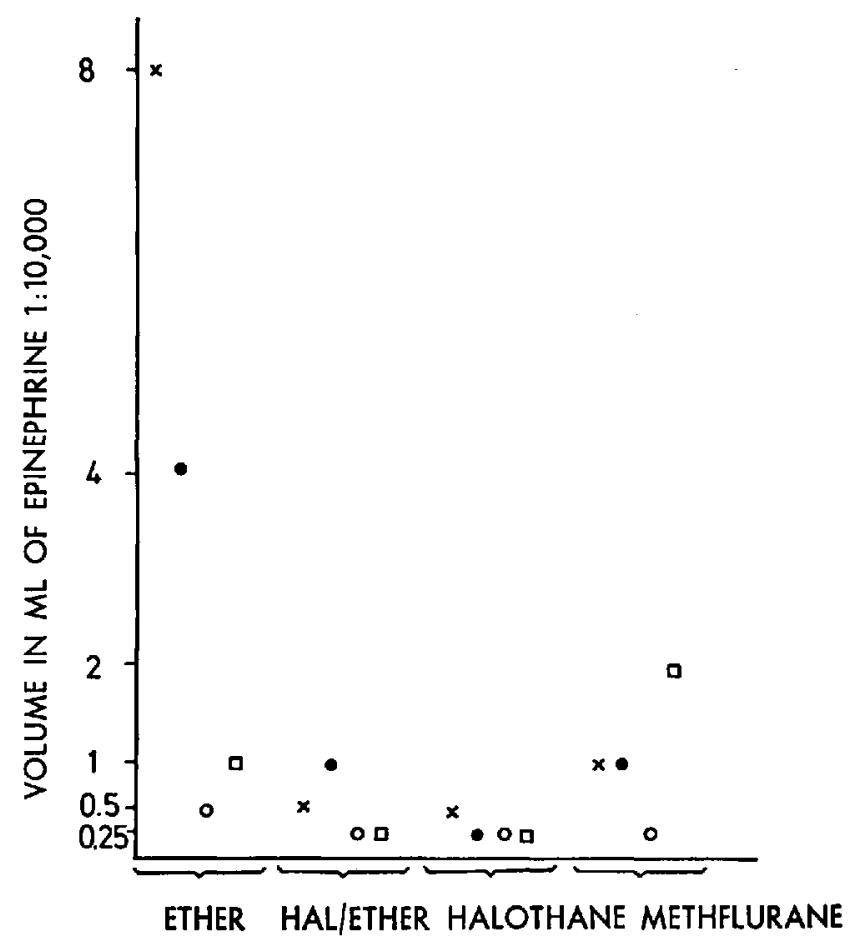

FIGURE 1. Each dog is represented by one distinctive symbol.

Mean baseline blood gas values of the four animals in the study were:

$\begin{array}{lc}\mathrm{pH} & 7.39 \\ \mathrm{Po}_{2} & 106 \\ \text { oxygen saturation } & 97.5 \% \\ \mathrm{~Pa}_{\mathrm{CO}_{2}} & 38.5 \\ \text { bicarbonate (actual) } & 23.08\end{array}$

No animal had an oxygen saturation of less than 95.5 per cent before any injection was given.

The times taken to revert to sinus rhythm in the present series are set out in Figure 2, which also shows results obtained in a preliminary pilot series. There is a good correlation between these two series, the propranolol-treated dogs faring no better than the controls. All arrhythmias reverted to sinus rhythm within 122 seconds, the mean time being 47 seconds and the minimum 17 seconds. It was not practicable to randomize the sequence of propranolol, saline and expectant treatment, since the first administration of propranolol might have influenced the others.

\section{Study II}

A second study was concerned with the elucidation of an incidental observation made in the course of the experiments previously described. It had been noted 


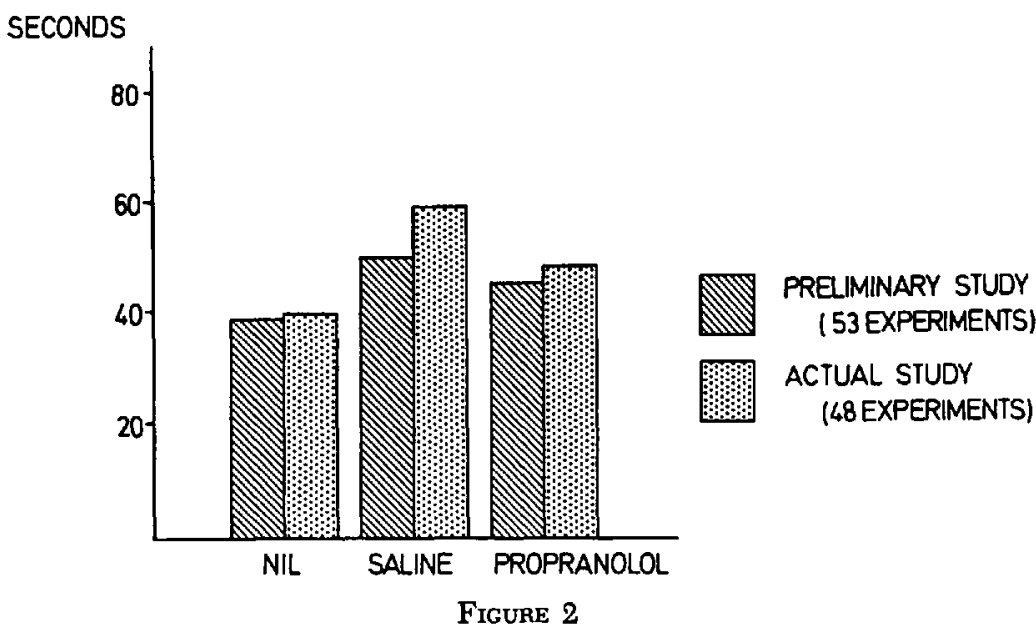

that, some time after propranolol had been injected, a majority of animals showed signs of decreased anaesthesia, manifested by spontaneous movements of ears or limbs which proceeded to a state of wakefulness in a number of instances. There was a tendency for the animals to settle down after some time without any change having been made in the anaesthetic mixture.

\section{Method}

This study was carried out on six dogs. The experimental design was similar to the one described above, except that the animals were allowed to breathe spontaneously to permit observation of changes in respiratory rate and pattern, should they occur. The doses of propranolol in this series differed. A total of $2.5 \mathrm{mg}$ was administered in $0.5 \mathrm{mg}$ increments over a period of ten minutes. Since the production of arrhythmias was not a part of this particular study, epinephrine was not injected.

\section{Results}

A fall of either systolic or diastolic pressure, or both, occurred following the injection of propranolol, irrespective of the anaesthetic agent administered. Although these changes were not substantial, they were consistent (Fig. 3). In no instance did the systolic pressure fall more than $45 \mathrm{~mm} \mathrm{Hg}$, nor the diastolic more than $20 \mathrm{~mm} \mathrm{Hg}$. These events were associated with marked tachypnoea (Fig. 4). Blood gases in this series revealed some metabolic acidosis before propranolol in 17 of 24 experiments, whereas after the drug acidosis remained uncompensated in only two instances (see Table I). That this change was due to the tachypnoea is confirmed by an unchanged bicarbonate in the presence of a rising $\mathrm{pH}$ and decreased $\mathrm{PCO}_{2}$ (Figs. 5 and 6).

\section{STUDY III}

Sinha and co-workers ${ }^{5}$ have successfully utilized the local anaesthetic properties of propranolol and have combined it with epinephrine to provide prolonged 

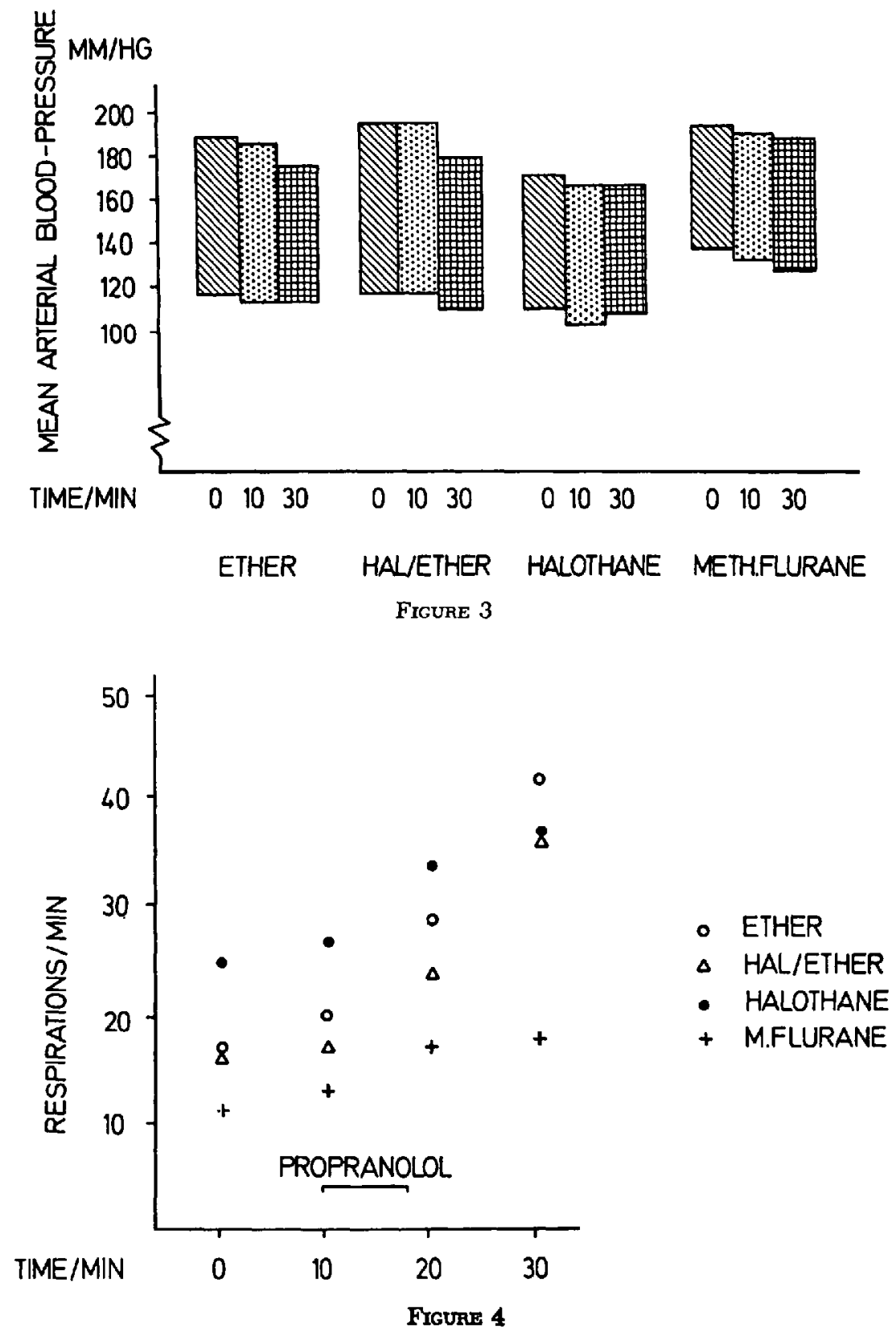

analgesia in patients requiring inflitration or topical anaesthesia. It is logical to expect that during general anaesthesia there would be less chance of provoking ventricular arrhythmias with this combination than by the use of epinephrine alone for the purpose of obtaining local vasoconstriction, as propranolol would be absorbed along with the epinephrine and so protect the myocardium. The third study was undertaken to test this hypothesis. 


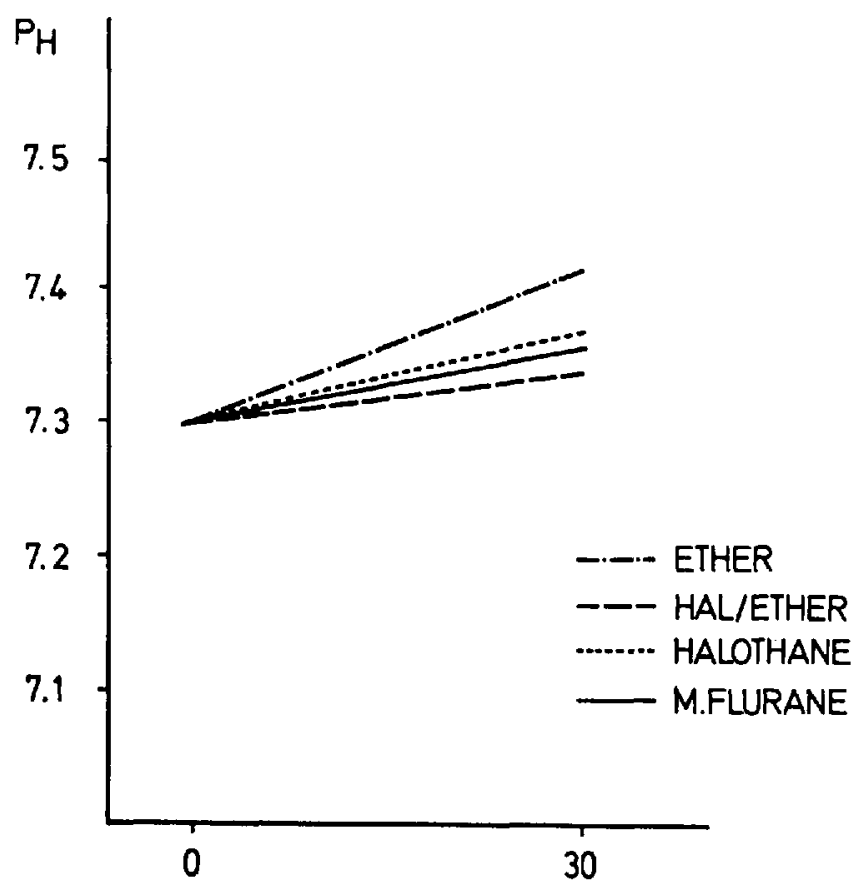

Ficure 5

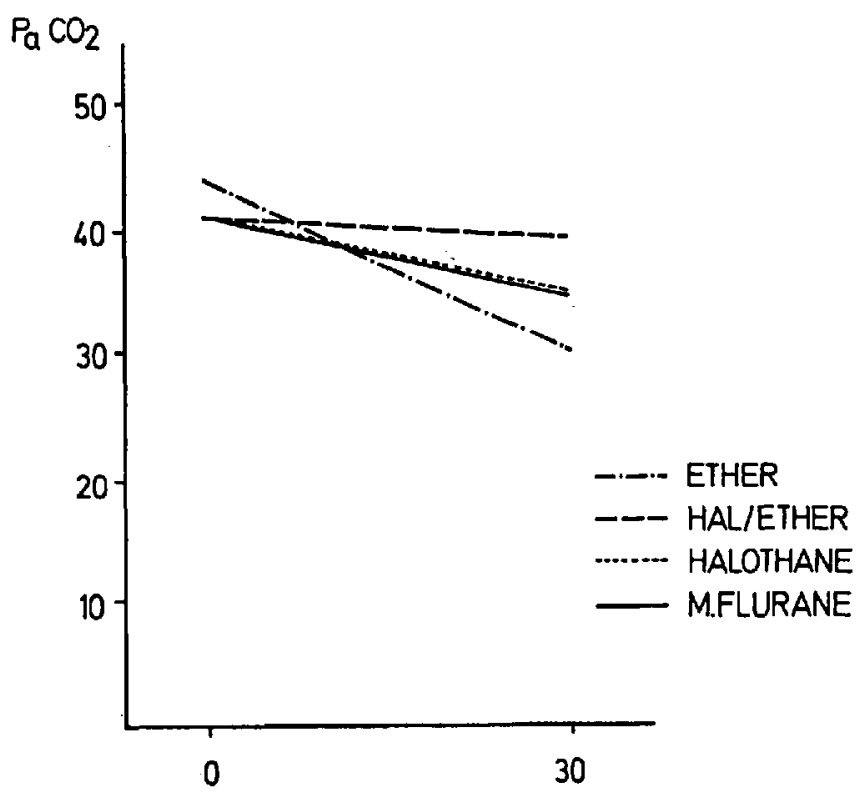

Figure 6 


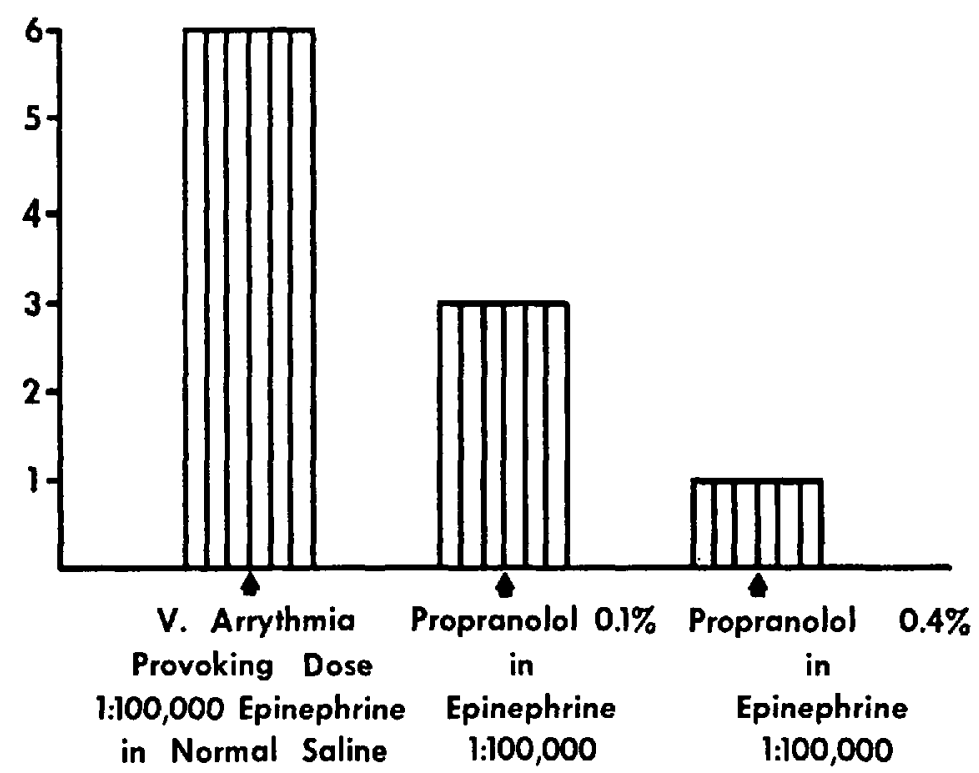

FIGURE 7. Number of dogs in which arrhythmia was provoked (vertical axis) with intravenous injections at weekly intervals, as shown.

\section{Method}

Six dogs weighing between 10 and 16 pounds were anaesthetized with an induction dose of thiopental ( 2.5 per cent) followed by orotracheal intubation and maintenance of anaesthesia with halothane 0.5 per cent in oxygen $9 \mathrm{~L} / \mathrm{min}$ through an Ayre's T-piece. Ventilation was spontaneous. After smooth maintenance of anaesthesia had been established, atropine $0.4 \mathrm{mg}$ was administered intravenously, followed by epinephrine 1:100,000 in normal saline, until ventricular arrhythmia had been induced. The amount of epinephrine injected was noted. One week later under the same conditions each animal received epinephrine 1:100,000 in propranolol 0.1 per cent, the dose of epinephrine being the same as that administered in the initial experiment. Finally, another week later, epinephrine 1:100,000 in propranolol 0.4 per cent was administered using five times the original arrhythmia-provoking dose of epinephrine.

\section{Results}

Only three of the six animals showed any arrhythmia following 0.1 per cent propranolol, and in five dogs further doses of up to eight times the original strength failed to provoke any arrhythmias. One animal exhibited multiple ventricular extrasystoles for four seconds during the early part of an injection of 0.4 per cent propranolol, but they disappeared during the course of the injection. Further injections of this solution up to $2 \mathrm{mg} / \mathrm{lb}$ propranolol (a gross overdose) failed to provoke any further arrhythmias in any animal. However, as extreme doses were reached, direct myocardial depression occurred. The results are summarized in Figure 7. 
TABLE I

Animals in Metabolic Acidosis

\begin{tabular}{lcc}
\hline & Before & After propranolol \\
\hline Ether & 3 & - \\
Halothane/ether & 5 & 1 \\
Halothane & 4 & 1 \\
Methoxyflurane & 5 & - \\
Total & 17 & 2 \\
\hline
\end{tabular}

It is of interest that during the slow injection of small doses of propranolol, deterioration of measured parameters was minimal, whereas when a higher dosage was employed (but still less than $1 \mathrm{mg} / \mathrm{lb}$ body weight) some animals suffered a significant drop in blood pressure and pulse rate. This only occurred, however, in those animals which had not received $0.4 \mathrm{mg}$ of atropine intravenously just prior to the experiments. They then responded immediately to intravenous atropine. On the other hand, when direct doses of propranolol exceeding $1 \mathrm{mg} / \mathrm{lb}$ body weight had induced myocardial depression, atropine failed to reverse the condition.

\section{DisCussion}

Epstein and Braunwald ${ }^{6}$ recommended that in the treatment of acute arrhythmias individual doses of propranolol should not exceed $0.5 \mathrm{mg}$ and that this dose should be repeated every three to four minutes until the desired effect is attained. In man an effect from propranolol was noted within three minutes of intravenous administration, which peaked in ten to fifteen minutes and lasted four to six hours. ${ }^{7}$ This being the case, it is by no means certain that the propranolol had time to act in the first study, where the average length of arrhythmia was only 47 seconds. It would be difficult to determine in any particular instance whether an epinephrineinduced arrhythmia might have been about to revert spontaneously just as propranolol was being injected. Examination of the electrocardiographic tracings reveals that most arrhythmias were ventricular tachycardia which changed to a bigeminal rhythm before reverting to sinus rhythm. Rapid distribution and metabolism of epinephrine is presumed to be the reason for this spontaneous reversion. It must be pointed out, however, that arrhythmias associated with the subcutaneous or intramuscular infiltration of epinephrine may well be more prolonged because of the continuing absorption of the drug.

The fact that during pilot experiments sudden death only occurred immediately after an epinephrine injection and not after any prolonged period of arrhythmia should make one cautious lest ventricular fibrillation occur in clinical practice before there has been an opportunity to administer propranolol or for it to take effect.

Our results provide no confirmation of the claim made by Johnstone ${ }^{8}$ and quoted in the promotional literature that ether anaesthesia precludes the use of propranolol to a greater degree than do other anaesthetics. However the possibility of a 
species difference in this regard must not be ignored. It is evident from our observations that propranolol has an arousal effect associated with tachypnoea, although the mechanism for it remains obscure.

It is the author's opinion that atropine in adequate amounts should be administered prior to propranolol injection, to prevent the autonomic imbalance, evidenced by a slowing of the pulse and lowering of the blood pressure, which is seen sometimes even after small intravenous doses of propranolol. While there is no direct evidence for this, one might contemplate that for the same reason atropine might be useful in the prevention of bronchospasm engendered by propranolol.

There is some evidence that the addition of propranolol to epinephrine for purposes of inflitration of the operative field has much to commend it, since it raises the threshold for arrhythmias. An incidental benefit of this regime lies in the local anaesthetic properties of propranolol which may permit a somewhat lighter plane of general anaesthesia to be maintained.

\section{SUMMARY}

Epeniphrine-induced arrhythmias in dogs during anaesthesia with diethyl ether, azeotrope halothane/ether, halothane, and methoxyllurane were treated with intravenous propranolol $0.5 \mathrm{mg}$. There was no demonstrable difference between dogs so treated and controls. All arrhythmias reverted within 122 seconds, with a mean reversal time of 47 seconds. It is suggested that propranolol may not have had time to exert its effect so soon and that the arrhythmias are self-limiting. A method of prophylaxis utilizing a propranolol-epinephrine solution for infiltration anaesthesia and vasoconstriction is suggested as a preferable alternative to treating epinephrine-induced arrhythmias with propranolol. An arousal effect, associated with hyperpnoea, was observed in propranolol during general anaesthesia.

\section{RÉSUMÉ}

Nous avons fait cette étude en trois phases. Au cours de la première, nous avons confirmé l'observation qu'une arythmie grave et même une fibrillation ventriculaire survient avec assez de facilité lorsqu’on associe halothane et épinéphrine mais que, lorsqu'on emploie l'éther diéthylique, ce phénomène est moins fréquent et il nous faut employer une plus grande quantité d'épinéphrine. De plus nous avons démontré que, si l'épinéphrine est donnée par voie endoveineuse, la fibrillation ventriculaire survient soudainement sans signe prémoniteur et sans arythmie ventriculaire préalable. Dans les cas où il apparaît seulement des arythmies, elles ont tendance à disparaître rapidement et un rythme sinusal apparaît à mesure que se métabolise l'épinéphrine et il demeure douteux que le propranolol puisse produire un effet appréciable sur la durée des arythmies si on le compare à un soluté salé dans le même traitement.

La deuxième phase de l'étude s'est concentrée sur l'élucidation de l'observation voulant que, après l'injection de propranolol, le niveau d'anesthésie devient beaucoup plus superficiel durant un certain temps avant de retourner au niveau où il 
était. Et cela en dépit du fait que aucun changement ne soit fait dans le débit du mélange anesthésique soit avant soit après le phénomène. Ce réveil s'accompagne d'une légère hypotension mais constante ainsi que d'une tachypnée importante. L'étiologie de ces observations demeure encore obscure.

$\mathrm{Au}$ cours de la troisième phase de cette étude, nous avons essayé de préciser si l'association épinéphrine-propranolol, lorsqu'injectée simultanément, pouvait réduire la fréquence de l'apparition d'arythmies cardiaques. De fait, il est résulté que ce phénomène existe et, puisque le propranolol possède également certaines propriétés anesthésiques locales, il semblerait opportun de réaliser cette association à chaque fois qu'un chirurgien pratique une infiltration d'épinéphrine au cours d'une anesthésie générale.

\section{REFERENCES}

1. Katz, R. L. \& Epstein, R. A. The Interaction of Anesthetic Agents and Adrenergic Drugs to Produce Cardiac Arrhythmias. Anesthesiology. 29: 763 (1968).

2. Johnstone, M. Propanolol (Inderal) during Halothane Anaesthesia. Brit. J. Anaesth. 38: 516 (1966).

3. Sharma, P. L. Effect of Propranolol Non-Catecholamine-Induced Arrhythmias during Nitrous Oxide-Halothane Anaesthesia in Dog. Brit. J. Anaesth. 38: 871 (1966).

4. Warner, W. A. Beta-Adrenergic Blocking Agents and Anaesthesia: A Review. Canad. Anaesth. Soc. J. 15: 42 (1968).

5. Sinha, J. N.; Jaju, B. P.; Misra, U. C.; Tewari, I. N.; \& Srimal, R. C. Clinical Efficacy of Propranolol as a Local Anaesthetic. Brit. J. Anaesth. 39: 887 (1967).

6. Epstein, S. E. \& Braunwald, E. Beta-Adrenergic Receptor Blocking Drugs: Mechanisms of Action and Clinical Applications. New England J. Med. 275: 1106 (1966).

7. Irons, G. V.; Ginn, W. N.; \& OrGain, E. S. Use of a Beta Adrenergic Receptor Blocking Agent (Propranolol) in the Treatment of Cardiac Arrhythmias. Am. J. Med. 43: 161 (1967).

8. Johnstone, M. Propranolol in Anaesthesia. Am. J. Cardiology. 18: 479 (1966). 